\title{
PENGARUH MODEL PEMBELAJARAN GENERATIF DENGAN TEKNIK GUIDED TEACHING TERHADAP KETERAMPILAN PROSES SAINS
}

\author{
Rasydah Nur Tuada, Gunawan, Susilawati \\ Program Studi Pendidikan Fisika \\ FKIP Universitas Mataram \\ Jalan Majapahit No. 62, Mataram \\ E-mail: rasydahnurtuada71096@gmail.com
}

\begin{abstract}
The purpose of this research is to know the effect of generative learning with guided teaching technique towards science process skills of students high school 7 Mataram. This research is a quasi-experimental with non-equivalent control group design. Population in research is all students class $X$ of high school 7 Mataram. Sampling method is cluster random sampling, with students sample of $X-E$ class (class experiment) and $X-C$ class (class control). Instruments used to measure of the science process skill is a multiple-choice grounded test. The initial ability of the experimental and control classes is homogeneous, so the effect of treatment is the result of the final test. Test the hypothesis using the t-test polled variants. Improved science process skills are determined based on the $N$-gain test. Interesting findings from the study indicate an increase in the science process skills in both classes. This show the generative learning with guided teaching techniques were applied successfully improve science process skills.
\end{abstract}

Keywords: science process skills, guided teaching technique, generative learning

\section{PENDAHULUAN}

Sains pada hakikatnya mencakup proses, produk, dan sikap. Fisika merupakan bagian dari sains yang memfokuskan kajiannya pada materi, energi, dan hubungan antara keduanya (Gunawan et. al., 2015). Sebagai sebuah produk, fisika merupakan sekumpulan pengetahuan tentang fakta, konsep, generalisasi, prinsip, teori dan hukum fisika. Sementara sebagai suatu proses, fisika merupakan serangkaian proses ilmiah yang dilakukan dalam menenemukan pengetahuanpengetahuan tentang fisika. Dalam pembelajaran sains terdapat keterampilan khusus yang harus dimiliki sebagai bentuk sains sebagai proses, yang disebut keterampilan proses sains (KPS). Menurut Darmawan et. al. (2015) keterampilan proses sains merupakan keterampilan ilmiah yang dilakukan dalam proses menemukan produk sains, termasuk fisika. Siswa akan mampu menemukan dan mengembangkan sendiri fakta dan konsep yang dipelajarinya dengan meningkatkan keterampilan proses sains yang dimiliki (Hardiyanto et. al., 2015).

Berdasarkan hasil wawancara dengan guru mata pelajaran fisika di SMA Negeri 7 Mataram terdapat beberapa hal yang menyebabkan rendahnya keterampilan proses sains siswa. Pada aspek keterampilan, guru masih belum melakukan pelatihan dan penilaian keterampilan proses sains secara spesifik. Pengembangan keterampilan proses sains siswa masih belum tersusun secara sistematis. Dalam proses pembelajaran guru belum memfokuskan pembelajaran pada keterampilan proses sains, sehingga siswa tidak terlatih dalam menerapkan keterampilanketerampilan ilmiah dalam proses pembelajaran. Metode pembelajaran yang sering digunakan oleh guru hanya ceramah, sehingga membuat siswa bosan dan keterampilan proses sainsnya kurang terlatih. 
Sistem pendidikan di indonesia yang hanya menekankan pada aspek produk semata ditandai dengan sistem Ujian Nasional (UN) sebagai evaluasi akhir pembelajaran fisika di sekolah juga kurang memperhatikan KPS siswa, karena evaluasi pembelajaran fisika semestinya dilakukan dari segi proses dan produk. Pembelajaran fisika tidak sebatas menuntut siswa untuk mengusai fakta, konsep, prinsip dan hukum semata, namun juga diharapkan siswa dapat menguasai seluruhnya melalui proses penemuan. Hal ini didukung penelitian Ambasari et. al. (2013) yang menyatakan bahwa pendidikan tidak hanya ditetapkan pada penguasaan materi, tetapi juga pada penguasaan keterampilan.

Permasalahan ini dapat diselesaikan dengan menggunakan model pembelajaran yang berpusat pada siswa. Salah satunya adalah model pembelajaran generatif yang berlandaskan paham konstruktivisme. Model pembelajaran generatif adalah model pembelajaran yang didesain dimana siswa secara aktif berpartisipasi secara langsung dalam proses pembelajaran dan mengkonstruksi makna dari informasi pengetahuan awal dan pengalaman yang dimiliki siswa. Hal ini sejalan dengan pendapat Nur (2015) yang menyatakan bahwa dengan menggunakan model pembelajaran generatif, siswa akan lebih aktif dalam mengikuti proses pembelajaran. Model pembelajaran generatif adalah suatu prosedur pembelajaran yang didasarkan pada suatu pandangan bahwa pengetahuan itu dikonstruksi oleh siswa itu sendiri (Lusiana, 2009)

Wena (2014) mengatakan bahwa model pembelajaran generatif pertama kali diperkenalkan oleh Osborne \& Cosgrove. Shoimin (2014) menyatakan bahwa teori belajar generatif merupakan suatu penjelasan tentang bagaimana seseorang siswa membangun pengetahuan dalam pikirannya, seperti membangun ide tentang sesuatu fenomena atau membangun arti untuk suatu istilah. Hal ini sejalan dengan pendapat Sugiana et. al. (2016) yang menyatakan bahwa model pembelajaran generatif merupakan model pembelajaran yang membimbing siswa dalam mengeksplorasi pengetahuan siswa untuk memperoleh pengetahuan baru. Model pembelajaran generatif efektif dalam mengintegrasikan beberapa proses penting dan menekankan peran penting dalam (a) kognitif, (b) pengetahuan awal, (c) pengalihan, dan (d) pembelajaran manusia di setiap generasi (Anderman, 2010). Dalam model pembelajaran generatif, siswa sendirilah yang lebih aktif secara mental membangun pengetahuannya, sedangkan guru lebih berperan sebagai fasilitator dan mediator dalam pembelajaran. Inti sari dari model pembelajaran generatif adalah otak tidak menerima informasi dengan pasif, tetapi aktif mengonstruksi interpretasi dari informasi kemudian membuat kesimpulan.

Wena (2014) membagi model pembelajaran generatif terdiri atas empat tahap, yaitu (a) pendahuluan atau disebut tahap eksplorasi, (b) pemfokusan, (c) tantangan atau tahap pengenalan konsep, dan (d) penerapan konsep. Menurut Wijaya et. al. (2014) model pembelajaran generatif, selain berorientasi pada pendekatan konsep, juga mengakomodasi pendekatan KPS dalam pelaksanaan pembelajarannya. Hal ini bisa dilihat pada fase eksplorasi/pendahuluan siswa dituntut untuk mengajukan pertanyaan dan mengkomunikasikan jawaban, kemudian pada fase pemusatan siswa diberikan kesempatan untuk mengajukan hipotesis dan pada fase tantangan siswa melakukan pengujian hipotesis dengan merencanakan dan melaksanakan percobaan.

Keunggulan dari model pembelajaran generatif menurut Marco dalam Putri et. al. (2014) yaitu, (a) memberikan kesempatan kepada siswa untuk mengungkapkan pikiran/ pendapat/ pemahamannya terhadap konsep, (b) 
melatih siswa untuk menghargai gagasan orang lain, (c) memberikan kesempatan kepada siswa untuk mengkonstruksi pengetahuannya sendiri, (d) dapat menciptakan suasana kelas yang aktif karena siswa dapat membandingkan gagasannya dengan gagasan siswa lainnya serta interfensi guru, (e) guru mengajar menjadi kreatif dalam mengarahkan siswanya untuk mengkonstruksi konsep yang akan dipelajari. Penelitian terkait dengan model pembelajaran generatif antara lain dilakukan oleh Wijaya et. al. (2014) menyatakan model pembelajaran generatif lebih efektif dalam meningkatkan keterampilan proses sains dibandingkan pembelajaran lansung.

Selain pemilihan model pembelajaran yang tepat penggunaan teknik pembelajaranpun berperan penting dalam proses pembelajaran. Salah satu teknik pembelajaran yang dapat digunakan adalah guided teaching. Teknik guided teaching merupakan satu teknik pembelajaran aktif dimana guru menanyakan satu atau lebih pertanyaan untuk membuka pengetahuan peserta didik.

Menurut Gumilar et. al., (2015) teknik guided teching adalah teknik dimana guru bertanya kepada peserta didik satu atau dua pertanyaan untuk mengetahui tingkat pemahaman peserta. Utomo et. al. (2012) menyatakan bahwa Guided teaching merupakan suatu perubahan dari ceramah secara langsung dan memungkinkan pendidik mempelajari apa yang telah diketahui dan di pahami para peserta didik sebelum membuat poin-poin pengajaran. Guided Teaching ini dapat mendorong siswa untuk ikut aktif selama proses pembelajaran. Model pembelajaran generatif dengan teknik guided teaching merupakan model pembelajaran yang menekankan pengintegrasian pengetahuan baru dengan pengetahuan yang dimiliki siswa sebelumnya menggunakan rangkaian penyampaian materi ajar diawali dari suatu pertanyaan yang dijadikan dasar menyampaikan materi berikutnya.

Belum adanya penggunaan model pembelajaran generatif yang digabungkan dengan teknik guided teaching, peneliti merasa tertarik untuk melakukan penelitian pada bidang studi fisika. Penggunaan model pembelajaran generatif yang digabungkan dengan teknik guided teaching sangat cocok digunakan di SMA Negeri 7 Mataram. Hal ini didukung dari hasil observasi awal, yang menunjukkan bahwa pembelajaran di kelas masih monoton. Pembelajaran generatif dengan teknik guided teaching diharapkan dapat meningkatkan keterampilan proses sains siswa pada pembelajaran fisika di tingkat sekolah menengah atas.

\section{METODE PENELITIAN}

Jenis penelitian yang digunakan adalah penelitian kuasi eksperimen dengan NonEquivalent control group design. Sebelum diberi perlakukan kedua kelompok sampel diberikan tes awal untuk mengukur kondisi awal. Selanjutnya kelas eksperimen diberikan perlakuan model pembelajaran generatif dengan teknik guided teaching dan kelas kontrol diberi perlakuan berupa model pembelajaran konvensional (direct instruction). Sesudah perlakuan, kedua kelas diberikan tes akhir.

Dalam penelitian ini ada 3 variabel yaitu variabel bebas yaitu model pembelajaran generatif dengan teknik guided teaching, variabel terikat yaitu keterampilan proses sains, variabel kontrol yaitu materi ajar yang diajarkan, guru yang mengajar, dan instrumen penilaian pada kelas eksperimen dan kontrol. Populasi dalam penelitian ini adalah seluruh siswa kelas $\mathrm{X}$ di SMAN 7 Mataram tahun ajaran 2016/2017 yang berjumlah 10 kelas. Teknik pengambilan sampel yang digunakan adalah cluster random sampling. Sampel yang digunakan adalah kelas X-E dengan jumlah 36 
siswa sebagai kelas eksperimen dan kelas X-C dengan jumlah 34 siswa sebagai kelas kontrol.

Pada penelitian ini, instrumen yang digunakan adalah tes keterampilan proses sains berbentuk pilihan ganda beralasan sebanyak 16 soal. Sebelumnya tes pilihan ganda di uji validitasnya sehingga diperoleh 16 soal yang valid. Uji-F digunakan untuk mengetahui homogenitas data dan uji normalitas untuk mengetahui apakah data terdistribusi normal atau tidak. Setelah itu, untuk mengetahui peningkatan nilai kedua tes sebelum dan sesudah diberi perlakuan digunakan uji t polled varians.

Selain uji hipotesis, dilakukan juga uji N-Gain. Sundayana (2014) menyatakan bahwa uji skor gain dilakukan untuk mengetahui seberapa besar peningkatan penguasaan konsep dengan kriteria terlihat pada Tabel 1.

Tabel 1 Kriteria Perolehan N-gain

\begin{tabular}{ccc}
\hline No. & Interval & Kriteria \\
\hline 1 & $\mathrm{~g}>70$ & Tinggi \\
2 & $30 \leq \mathrm{g} \leq 70$ & Sedang \\
3 & $\mathrm{~g}<30$ & Rendah \\
\hline
\end{tabular}

\section{HASIL DAN PEMBAHASAN}

Penelitian ini bertujuan untuk mengetahui apakah ada pengaruh penggunaan model pembelajaran generatif dengan teknik guided teaching terhadap keterampilan proses sains siswa kelas X SMA Negeri 7 Mataram. Adapun keterampilan proses sains siswa sebelum diberikan perlakuan terlihat dari nilai tes awalnya (pre-test), dan penguasaan konsep setelah diberikan perlakuan terlihat dari nilai tes akhir (post-test). Tes keterampilan proses sains yang diberikan adalah tes tertulis berbentuk pilihan ganda beralasan. Tes awal dilakukan untuk mengetahui homogenitas serta normalitas sampel. Adapun hasil tes awal dapat dilihat pada Gambar 1.

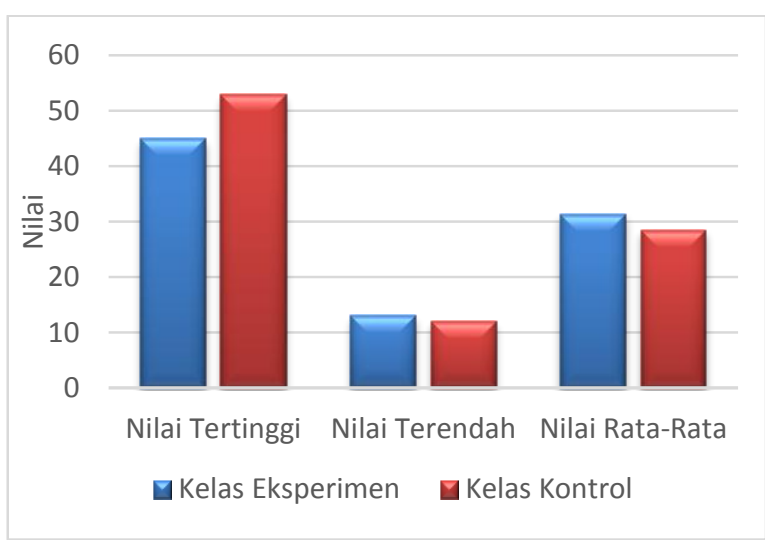

Gambar 1. Perbandingan Hasil Tes Awal Keterampilan Proses Sains Siswa

Berdasarkan Gambar 1 terlihat bahwa nilai tertinggi untuk kelas eksperimen adalah 45 sedang kelas kontrol adalah 53. Nilai terendah pada kelas eksperimen yaitu 13 dan pada kelas kontrol 12. Nilai rata-rata kelas eksperimen 31,36 dan rata-rata nilai kelas kontrol 28,47. Kemampuan akhir diperoleh dari tes akhir setelah diberikan perlakuan. Tes akhir diberikan untuk mengetahui normalitas dan hipotesis penelitian. Adapun hasil tes akhir dapat dilihat pada Gambar 2.

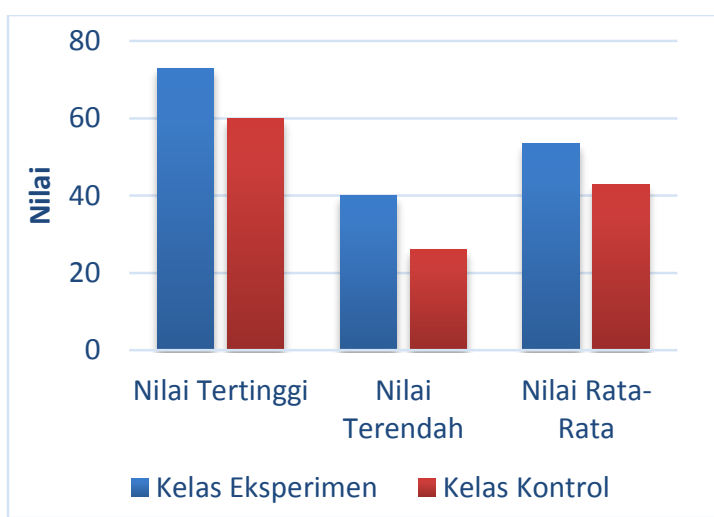

Gambar 2 Hasil Tes Akhir Keterampilan Proses Sains Siswa

Gambar 2 menunjukan kelas eksperimen memiliki kemampuan akhir lebih tinggi dibandingkan kelas kontrol. Nilai tertinggi untuk kelas eksperimen adalah 73 dan kelas kontrol adalah 60 sedangkan untuk nilai terendah pada kelas eksperimen adalah 40 dan pada kelas kontrol 28. Rata-rata nilai kelas eksperimen 53,39 dan rata-rata nilai kelas kontrol 42,85.Pengujian data keterampilan 
proses sains siswa pada kedua kelas diawali dengan tes awal dan tes akhir. Kemudian, dilanjutkan uji homogenitas, uji normalitas, dan uji hipotesis menggunakan uji-t polled.

Berdasarkan uji homogenitas pada tes awal dan tes akhir disimpulkan bahwa data kedua kelas homogen.Berdasarkan uji normalias yang telah dlakukan diperoleh hasil bahwa data kedua kelas terdistribusi normal. Hasil tes awal diperoleh nilai $\chi^{2}$ hitung sebesar 3,43 untuk kelas eksperimen dan 5,11 untuk kelas kontrol. Nilai $\chi^{2}$ tabel sebesar 11,07 dengan taraf signifikan 0,05 untuk kedua kelas, sehingga $\chi^{2}$ hitung $^{2} \chi^{2}$ tabel yang berarti data tes awal untuk kedua kelas terdistribusi normal. Hasil tes akhir nilai $\chi^{2}$ hitung untuk kelas eksperimen sebesar 9,02 dan untuk kelas kontrol sebesar 6,26 Nilai $\chi^{2}$ tabel dengan taraf signifikan 0,05 untuk kedua kelas adalah 11,07 sehingga data tes akhir kedua kelas terdistribusi normal.

Selanjutnya dilakukan uji hipotesis untuk mengetahui adanya pengaruh model pembelajaran generatif dengan teknik guided teaching terhadap keterampilan proses sains. Uji hipotesis menggunakan statistik parametrik karena data homogen dan terdistribusi normal. Uji hipotesis yang digunakan adalah uji-t polled varians karena sampel pada penelitian ini berbeda $\left(n_{1} \neq n_{2}\right)$. Hasil uji statistik yang dilakukan diperoleh nilai thitung sebesar 6,023. Nilai thitung tersebut lebih besar dibandingkan nilai $t_{\text {tabel, }}$ yaitu 1,99 pada taraf signifikan 0,05. Sehingga model pembelajaran generatif dengan teknik guided teaching berpengaruh terhadap peningkatan keterampilan proses sains siswa.

Terjadinya peningkatan ini merupakan pengaruh selama pembelajaran. Keberhasilan penggunanaan model pembelajaran generatif dengan teknik guided teaching disebabkan karena dalam pembelajaran siswa mencari pengetahuannya sendiri serta membuat siswa lebih aktif dalam bekerja dan berpikir. Hal ini sejalan dengan pendapat Putri, et.al (2014) yang menyatakan bahwa Model pembelajaran generatif berpusat pada siswa karena model pembelajaran ini mendorong siswa untuk membentuk pengetahuannya sendiri dan guru berperan sebagai fasilitator yang memfasilitasi siswa dalam proses pembelajaran dan membimbing siswa dalam pengkontruksian pengetahuan dengan cara menyambungkan pengetahuan awal siswa dengan materi baru yang akan dipelajari dalam pembelajaran.

Menurut Rusman dalam Darmawan et. al. (2015) masalah dapat mendorong keseriusan (keingintahuan). Keingintahuan siswa pada suatu masalah ini difasilitasi melalui teknik guided teaching yaitu memberikan pertanyaan kepada siswa untuk membuka pengetahuan yang dimilikinya. Dalam proses pembelajaran siswa diberikan kesempatan untuk mencari dan menemukan sendiri berbagai jawaban atas persoalanpersoalan yang dihadapinya dengan mengadakan percobaan pada tahap tantangan. Selama pembelajaran materi kalor dan perpindahan kalor, siswa melakukan praktikum sebanyak 3 pertemuan. Setiap praktikum yang dilaksanakan, siswa dituntut untuk mengisi lembar kerja siswa (LKS). LKS yang digunakan menuntut proses penyelesaian masalah dalam pembelajara yang mencakup empat aspek keterampilan proses sains siswa yang sedang diteliti dan dirancang sesuai dengan praktikum yang sedang dilakukan. Dengan demikian, dalam melakukan kegiatan eksperimen siswa melalukan pemecahan masalah dalam pembelajaran generatif dengan teknik guided teaching menggunakan keterampilan proses sains yang diteliti. Secara tidak langsung proses tersebut melatih keterampilan proses sains siswa menjadi lebih baik.

Ditinjau dari tahapan pembelajaran (sintaks) model pembelajaran generatif, ada beberapa KPS yang bisa dikembangkan. Pada 
fase eksplorasi, guru menggali konsepsi awal siswa dengan memberikan sejumlah pertanyaan dengan teknik guided teaching. Dalam hal ini siswa dituntut untuk mampu menyampaikan konsepsi awalnya dengan jelas dan lancar, sehingga salah satu aspek KPS yaitu mengkomunikasikan dilatih dalam fase eksplorasi. Pada fase pemfokusan, guru memberikan pertanyaan-pertanyaan terbuka kepada siswa untuk memusatkan pada konsep yang akan dipelajari. Pemberian pertanyaan terbuka akan melatih siswa untuk berhipotesis dan mampu mengkomunikasikan jawaban dengan jelas. Kemudian pada fase tantangan, siswa membuktikan hipotesis melalui kegiatan percobaan, dilanjutkan dengan penyajian hasil percobaan serta diskusi kelas. Pada fase pemusatan ini siswa akan dilatih untuk mampu menginterpretasi data yang diperoleh saat melakukan percobaan, selain itu siswa mampu mengkomunikasikan hasil percobaan dan mengajukan pertanyaan terkait hasil percobaan temannya. Selanjutnya, pada fase penerapan konsep guru memberikan soal dan permasalahan untuk menguji pemahaman siswa. Dalam fase ini, kemampuan siswa dalam memprediksikan berbagai jawaban atas soal dan permasalahan tersebut sangat diperlukan.

Selain melakukan uji hipotesis peneliti juga ingin mengetahui sejauh mana peningkatan yang dialami kedua kelas secara lebih terperinci terkait hubungan nilai kelas kontrol dan kelas eksperimen untuk persentase kenaikan keterampilan proses sains tiap indikator. Terdapat empat indikator keterampilan proses sains: (a) merumuskan hipotesis, (b) melakukan eksperimen, (c) Interpretasi data, (d) mengkomunikasikan. Setiap indikator dianalisis ketercapaiannya berdasarkan perolehan skor tes awal dan tes akhir dan gain ternormalisasi. Perbandingan peningkatan keterampilan proses sains tiap indikator ditunjukan dalam Gambar 3.

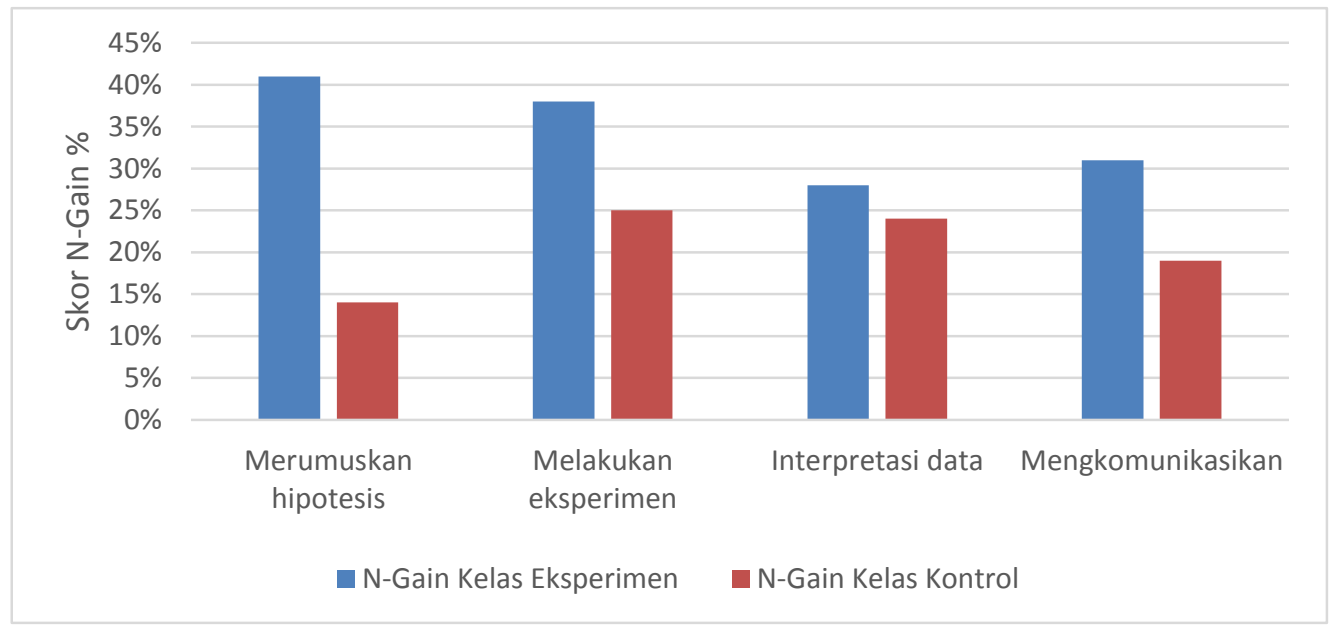

Gambar 3. Nilai N-gain Tiap Indikator

Berdasarkan gambar 3 dapat di lihat bahwa pada kelas eksperimen aspek keterampilan proses sains yang paling meningkat adalah indikator pertama yaitu merumuskan hipotesis dengan persentase sebesar $40 \%$, sedangkan kelas kontrol sebesar 14\%. Peningkatan pada kelas eksperimen tergolong sedang dan kelas kontrol tergolong rendah. Perbedaan yang sangat jauh antara kelas eksperimen dengan kelas kontrol di pengaruhi beberapa sebab, diantaranya yang terlihat jelas adalah perbedaan di LKS yang digunakan. Kelas eksperimen di latih untuk mengembangkan kemampuan berhipotesis 
yang di sajikan dalam LKS yang digunakan, siswa di tuntut untuk memberikan hipotesis atas sebuah permasalahan. Hal ini terjadi karena pada LKS kelas eksperimen aspek merumuskan hipotesis lebih terarah langsung ke pokok materi yang dipelajari sedangkan pada kelas kontrol siswa hanya melakukan eksperimen sesuai tahapan LKS.

Aspek keterampilan proses sains yang kedua adalah melakukan eksperimen. Kelas eksperimen mengalami persentase peningkatan sebesar 38\%, sedangkan kelas kontrol sebesar $25 \%$. Peningkatan pada kelas eksperimen dan kelas kontrol tergolong rendah. Peningkatan ini dapat terjadi karena siswa terlibat langsung dalam melakukan percobaan, sehingga melatih kemampuan eksperimennya. Pada LKS terdapat langkah kerja yang dapat siswa ikuti, sehingga memudahkan dalam melakukan eksperimen. Penyebab peningkatan kemampuan keterampilan siswa rendah disebabkan oleh kemampuan awal siswa yang tergolong rendah karena jarang dilakukannya eksperimen saat kegiatan belajar mengajar berlangsung.

Aspek keterampilan proses sains yang ketiga adalah mengkomunikasikan. Kelas eksperimen mengalami persentase peningkatan sebesar $31 \%$, sedangkan kelas ekperimen sebesar 19\%. Peningkatan keterampilan proses sains pada kelas ekperimen tergolong rendah, sedangkan kelas kontrol tergolong sangat rendah. Peningkatan pada kelas ekperimen lebih tinggi dibandingkan kelas kontrol karena pada kelas eksperimen terdapat fase tantangan dimana siswa tidak hanya melakukan eksperimen tetapi juga mempresentasikan hasil percobaan yang diperoleh, selain itu siswa dilatih untuk saling menanggapi ide atas hasil percobaan dari setiap kelompok sehingga melatih kemampuan mengkomunikasikan. Penyebab peningkatan aspek keterampilan proses sains tergolong rendah adalah siswa masih sulit untuk mengungkapkan ide atau pemikiran atas suatu permasalahan. Siswa kurang terlatih dalam membaca grafik yang diperoleh.

Aspek keterampilan proses sains yang terakhir adalah interpretasi data. Kelas eksperimen mengalami persentase peningkatan sebesar 28\%, sedangkan kelas ekperimen sebesar 24\%. Peningkatan keterampilan proses sains pada kelas ekperimen dan kelas kontrol tergolong rendah. Peningkatan pada kelas eksperimen lebih tinggi dibandingkan kelas kontrol karena pada kelas ekperimen menggunakan model pembelajaran generatif dengan teknik guided teaching dimana melatih siswanya untuk berpikir tingkat tinggi, menghubungkan konsep yang satu dengan yang lain, serta dibimbing secara terarah oleh guru. Peningkatan tergolong rendah karena Interpretasi data merupakan salah satu indikator yang sulit, siswa dituntut untuk menggabungkan hasil-hasil pengamatan, serta menemukan pola dalam suatu seri pengamatan. Kemampuan siswa dalam interpretasi data sangat dibutuhkan untuk pengujian hipotesis ataupun menyimpulkan suatu percobaan.

Berdasarkan data yang diperoleh menunjukkan bahwa kelas eksperimen yang diberikan perlakuan berupa model pembelajran generatif dengan teknik guided teaching memiliki keterampilan proses sains fisika yang lebih tinggi daripada kelas kontrol. Hal ini karena, model pembelajaran generatif dengan teknik guided teaching memberikan kesempatan kepada siswa untuk menyelesaikan suatu permasalahan melalui pengetahuan yang dimiliki sebelumnya sekaligus melatih keterampilan proses sains dengan sintak yang lebih terarah. Model pembelajaran langsung merupakan model pembelajaran yang merancang proses transfer pengetahuan dari guru ke siswa. Dalam model pembelajaran ini, guru berperan sebagai narasumber bukan fasilitator. Siswa 
memperoleh pengetahuan dengan cara transfer pengetahuan dari guru dan bukan dari aktivitas proses sains serta kegiatan ilmiah. Dengan demikian, keterampilan proses sains siswa akan sulit dikembangkan.

Hasil penelitian ini juga didukung oleh penelitian-penelitian sebelumnya mengenai model pembelajaran generatif. Wijaya et. al., (2014) menyatakan bahwa model pembelajaran generatif lebih efektif dalam meningkatkan keterampilan proses sains dibandingkan dengan model pembelajaran langsung. Menurut Pratama et. al., (2016) Model pembelajaran generatif dapat meningkatkan motivasi dan hasil belajar fisika siswa. Juraini et. al., (2015) menyatakan bahwa melatihkan keterampilan proses merupakan salah satu upaya yang penting untuk memperoleh keberhasilan belajar siswa yang optimal.

\section{PENUTUP}

Keterampilan proses sains merupakan keseluruhan keterampilan ilmiah yang terarah baik kognitif maupun psikomotor yang dapat digunakan untuk menemukan suatu konsep atau prinsip atau teori. Berdasarkan uji hipotesis, dapat disimpulkan bahwa terdapat perbedaan keterampilan proses sains fisika siswa antara kelas eksperimen yang diberikan perlakuan berupa model pembelajaran generatif dengan teknik guided teaching terhadap kelas kontrol yang diberikan perlakuan berupa penerapan model pembelajaran konvensional. Karena keterampilan proses sains kelas eksperimen lebih tinggi dari kelas kontrol maka dapat dikatakan bahwa model pembelajaran generatif dengan teknik guided teaching berpengaruh positif terhadap keterampilan proses sains siswa SMA Negeri 7 Mataram.

\section{REFERENSI}

Anderman, E.M. 2010. Reflection on Wittrock's Generative Model of Learning: A Motivation Perspective. Educational Psychologist. 45(1), 55-60.

Ambasari, W., Santosa. S., \& Maridi. 2013. Penerapan Pembelajaran Inkuiri Terbimbing terhadap Keterampilan Proses Sains Dasar pada Pembelajaran Biologi Siswa kelas VIII Negeri 7 Surakarta. Jurnal Pendidikan Biologi. 5(1), 81-95.

Darmawan, Sutrio, \& Wahyudi. 2015. Pengaruh Pembelajaran Berbasis Masalah Melalui Metode Eksperimen Terhadap Keterampilan Proses Sains Fisika Siswa SMA Negeri 1 Selong Tahun Ajaran 2014/2015. Jurnal Pendidikan Fisika dan Teknologi. 1(3), 160-165

Gunawan, Harjono, A. \& Sutrio. 2015. Multimedia Interaktif Dalam Pembelajaran Konsep Listrik Bagi Calon Guru. Jurnal Pendidikan Fisika dan Teknologi. 1(1), 9-14.

Gumilar, G. \& Sulistyio, E. 2015. Pengaruh Model Pembelajaran Aktif Guided Teaching Terhadap Hasil Belajar Siswa Pada Standar Kompetensi Merekam Audio di studio SMKN 2 Surabaya. Jurnal Pendidikan Tekhnik Elektro. 4(2), 633-638.

Hardiyanto, Susilawati \& Harjono,A. 2015. Pengaruh Model Pembelajaran Berbasis Masalah dan Ekspositori dengan Keterampilan Proses Sains Terhadap Hasil Belajar Fisika Siswa Kelas VII MTsN 1 Mataram Tahun Ajaran 2014/2015. Jurnal Pendidikan Fisika dan Teknologi (1), 249-256.

Juraini, Tufik, M. \& Gunada, I.,W. 2015. Pengaruh Model Pembelajaran Kooperatif Tipe STAD (Student Team Achievement Division) dengan Metode Eksperimen Terhadap Keterampilan Proses Sains dan Hasil Belajar Fisika Pada Siswa SMA Negeri 1 Labuapi 
Tahun Pelajaran 2015/2016. Jurnal Pendidikan Fisika dan Teknologi 2(2), 80-85.

Lusiana, Hartono, Y., \& Saleh, T. 2009. Penerapan Model Pembelajaran Generatif (MPG) untuk Pelajaran Matematika di Kelas X SMAN 8 Palembang. Jurnal Pendidikan Matematika. 3(2): 30-31.

Nur, A. 2015. Penerapan Model Pembelajaran Generatif Untuk Meningkatkan Hasil Belajar Fisika Siswa Kelas XI IPA1 SMA Negeri 9 Makassar. Jurusan Pendidikan Fisika Universitas Muhammadiyah Makassar. 3(1), 1-13

Pratama, A., Hamid, T., \& Halim, A. 2016. Penerapan Model Pembelajaran Generatif Dengan Menggunakan Virtual Laboratorium Untuk Meningkatkan Hasil Belajar Siswa. Jurnal Ilmiah Mahasiswa (JIM) Pendidikan Fisika. 2(1): 149-153.

Putri, G.A.A.A., Putra, D.B.K.N.S., \& Suardika, I.W.R. 2014. Pengaruh Penerapan Model Pembelajaran Generatif Berbasis Bekerja Ilmiah Terhadap Hasil Belajar IPA Siswa Kelas V SD Gugus Mayor Metra Denpasar Utara Tahun Ajaran 2013/2014. Ejournal MIMBAR PGSD Universitas Pendidikan Ganesha Jurusan PGSD. 2(1): 1-10.

Shoimin, A. 2014. 68 Model Pembelajaran Inovatif dalam Kurikulum 2013. Yogyakarta: Ar-Ruzz Media.

Sugiana, I. N., Harjono, A., Sahidu, H. \& Gunawan. 2016. Pengaruh Model Pembelajaran Generatif Berbantuan Media Laboratorium Virtual Terhadap Penguasaan Konsep Fisika Siswa pada Materi Momentum dan Impuls. Jurnal Pendidikan Fisika dan Teknologi 2(2). $1-5$.

Sundayana, R. 2014. Statistika Penelitian Pendidikan. Bandung: Alfa Beta

Utomo, N.T.P \& Sulistyo, E. 2012. Pengembangan Perangkat Pembelajaran
Aktif Dengan Model Guided Teaching Pada Standar Kompetensi Memperbaiki Compact Cassette Recorder Di SMK Negeri 1 Madiun. Tekhnik Elektro UNESA 1(2): 1-9.

Wena, M. 2014. Strategi Pembelajaran Inovatif Kontemporer. Jakarta: Bumi Aksara.

Wijaya, I.K.W.B., Suastra, I.W. \& Muderawan, I.W. 2014. Pengaruh Model Pembelajaran Generatif Terhadap Keterampilan Berpikir Kreatif Dan Keterampilan Proses Sains. e-Journal Program Pascasarjana Universitas Pendidikan Ganesha Program Studi Pendidikan IPA. 4, 1-11. 